\title{
GLOSA DO WYROKU NACZELNEGO SĄDU ADMINISTRACYJNEGO Z DNIA 29 SIERPNIA 2013 R., II OSK 848/12
}

\section{COMMENTARY ON JUDGMENT OF THE SUPREME ADMINISTRATIVE COURT OF 29 AUGUST 2013, II OSK $848 / 12$}

Słowa kluczowe

Postępowanie administracyjne, ciężar dowodu, prawo ochrony środowiska.

\section{Keywords} law.

Administrative proceedings, the burden of proof, environmental

Prof. dr hab., Kierownik Katedry Prawa Ochrony Środowiska UMK w Toruniu, radca prawny. 
„W postępowaniu administracyjnym, niezależnie od tego, czego postępowanie to dotyczy, ciężar dowodu w znaczeniu formalnym obciąża przede wszystkim organ administracji publicznej, chyba że przepis szczególny stanowi inaczej. W ustawie szkodowej regulacji szczególnej brak, co oznacza, że organy ochrony środowiska musiały kierować się przepisami kpa, a nie art 6 kc".

Glosowany wyrok NSA nie był do tej pory tezowany. Jego analiza wskazuje jednak, że kluczowym problemem, który rozważał Naczelny Sąd Administracyjny jest kwestia rozkładu ciężaru dowodu w postępowaniach wywołanych zgłoszeniem szkody w środowisku w trybie art. 24 ustawy z dnia 13 kwietnia 2007 o zapobieganiu szkodom w środowisku i ich naprawie ${ }^{1}$.

Zaproponowana teza, będąca cytatem uzasadnienia, oddaje jednak sposób rozumowania NSA co do rozkładu ciężaru dowodu według ustawy szkodowej. Problem ciężaru dowodu w ustawie szkodowej jest niezwykle interesujący z punktu twierdzenia teoretycznego, gdyż wpisuje się w szersze zagadnienie, jakim jest problematyka ciężaru dowodu w prawie ochrony środowiska, a nawet szerzej, w postępowaniach administracyjnych in genere. Rozkład ciężaru dowodu ma również doniosłe znaczenie praktyczne, stąd też tematyka ta warta jest rozważenia i skomentowania.

Dalszym powodem, dla którego warto owo orzeczenie komentować, jest zmiana poglądów sądów administracyjnych co do rozkładu ciężaru dowodu w postępowaniach wszczynanych na podstawie zgłoszenia dokonanego w trybie art 24 ustawy szkodowej. NSA prezentował do tej pory właściwą linię orzecznictwa co do rozkładu ciężaru dowodu w sprawach inicjowa- 
nych zgłoszeniem szkody w środowisku (tak chociażby wyrok NSA z dnia 14 czerwca 2013 II OSK 417/12).

Samo rozstrzygnięcie sądu oddalające skargę kasacyjną Fundacji należy przyjąć z aprobatą. Niemniej krytycznie trzeba ocenić wyrażony przez NSA pogląd ujęty w tezie wyroku, a dotyczący rozkładu ciężaru dowodu.

Glosowane orzeczenie zapadło w związku z rozpoznawaniem skargi kasacyjnej Fundacji od wyroku WSA w Warszawie z dnia 11 stycznia 2012 roku sygn IV SA/Wa 1760/11, którym to wyrokiem oddalono skargę tej Fundacji na decyzję Generalnego Dyrektora Ochrony Środowiskowa. Zaskarżoną decyzją Generalny Dyrektor Ochrony Środowiska utrzymał w mocy decyzję Regionalnego Dyrektora Ochrony Środowiska w Szczecinie, którą to decyzją odmówiono nałożenia na podmiot korzystający ze środowiska obowiązku przeprowadzenia działań zapobiegawczych i naprawczych.

Skarżąca Fundacja dokonała zgłoszenia szkody w środowisku w trybie art. 24 ustawy szkodowej. W zgłoszeniu Fundacja podnosiła, że do szkody w środowisku miało dojść poprzez zamknięcie otworów wentylacyjnych w stropodachach. Generalny Dyrektor Ochrony Środowiska w decyzji II-instancyjnej wskazał, iż przepisy ustawy szkodowej odnoszą się wyłącznie do przypadków, których bezpośrednie zagrożenie szkodą w środowisku lub szkoda $\mathrm{w}$ środowisku spowodowane zostały przez działalność podmiotu korzystającego ze środowiska prowadzącego działalność stwarzającą ryzyko takiej szkody. Organ II instancji wskazał, że nie doszło do wyczerpania wszystkich przesłanek zastosowania ustawy szkodowej.

Wojewódzki Sąd Administracyjny oddalając skargę, wskazał, że do zastosowania ustawy szkodowej nie wystarczy jedynie spełnienie przez podmiot zgłaszający wymogów formalnych, ale konieczne jest również stwierdzenie przez organ zasadności zgłoszenia. Jako podstawowy motyw oddalenia skargi wskazano 
brak wykazania stanu początkowego i obciążający zgłaszającego ciężar dowodu początkowego. WSA ustalił, że Fundacja poza twierdzeniami dotyczącymi stanu początkowego nie przedstawiła żadnego dowodu, który by pozwolił zanegować stanowisko podmiotu korzystającego ze środowiska co do zasadności zgłoszenia. W skardze kasacyjnej Fundacja zarzuciła naruszenie przepisów ustawy o postępowaniu przed sądami administracyjnymi, między innymi przez to, że zaniechano przeprowadzenia dowodu z dokumentów w postaci umowy, pozwolenia na budowę, dziennika budowy, zgłoszenia rozpoczęcia i zakończenia prac, a także zaniechano przeprowadzenia dowodu z zeznań świadka. Fundacja zarzucała również, iż WSA w Warszawie naruszył przepisy akceptując stanowisko Generalnego Dyrektora Ochrony Środowiska.

\section{III}

Stanowisko Naczelnego Sądu Administracyjnego co do kwestii ciężaru dowodu w postępowaniach prowadzonych w trybie art. 24 ustawy szkodowej należy ocenić negatywnie. Przede wszystkim NSA jest niekonsekwentny w prezentowaniu swoich argumentów. Trudno odmówić NSA racji, gdyż stwierdza On, że co do zasady ciężar dowodu w znaczeniu formalnym obciąża przede wszystkim organ administracji publicznej. Wyjątek od tej reguły może być wprowadzony jedynie w przepisie szczególnym, niemniej, zdaniem tego Sądu, art. 24 ustawy szkodowej nie jest takim przepisem szczególnym. Tego ostatniego stwierdzenia nie sposób zaakceptować.

Zgodnie z art. 24 ustawy szkodowej „1. Organ ochrony środowiska jest obowiązany przyjąć od każdego zgłoszenie o wystąpieniu bezpośredniego zagrożenia szkodą w środowisku lub szkody w środowisku.

2. Jeżeli zagrożenie szkodą $\mathrm{w}$ środowisku lub szkoda w środowisku dotyczy środowiska jako dobra wspólnego, zgłoszenia, o którym mowa w ust. 1, może dokonać 
organ administracji publicznej albo organizacja ekologiczna.

3. Zgłoszenie, o którym mowa w ust. 1 i 2, zawiera:

1) imię i nazwisko albo nazwę podmiotu zgłaszającego bezpośrednie zagrożenie szkodą $\mathrm{w}$ środowisku lub szkody w środowisku, jego adres zamieszkania albo adres siedziby;

2) określenie rodzaju, opis, wskazanie miejsca i datę wystąpienia bezpośredniego zagrożenia szkodą w środowisku lub szkody w środowisku.

4. Zgłoszenie, o którym mowa w ust. 1 i 2, powinno w miarę możliwości zawierać dokumentację potwierdzającą wystąpienie bezpośredniego zagrożenia szkodą w środowisku lub szkody w środowisku lub wskazanie odpowiedzialnego podmiotu korzystającego ze środowiska.

5. Organ ochrony środowiska, uznając za uzasadnione zgłoszenie, o którym mowa w ust. 1 i 2, postanawia o wszczęciu postępowania w sprawie wydania decyzji, o której mowa w art. 15 ust. 1, albo w przypadkach, o których mowa w art. 16, podejmuje działania zapobiegawcze lub naprawcze; art. 17 stosuje się odpowiednio.

6. Podmioty, o których mowa w ust. 2, które dokonały zgłoszenia, mają prawo uczestniczyć $\mathrm{w}$ postępowaniu na prawach strony.

7. Organ ochrony środowiska odmawia wszczęcia postępowania w drodze postanowienia, na które przysługuje zażalenie".

Przepis ten zawiera charakterystyczną i jednocześnie nietypową regulację. Po pierwsze, w grę wchodzi dwuetapowość postępowania (czy też inaczej dwa odrębne postępowania), co przypomina konstrukcję procesu karnego; po drugie, ust. 3 i 4 wyraźnie przerzuca ciężar dowodu na podmiot zgłaszający. W tym też kontekście istotnego znaczenia nabiera samo zgłoszenie i podejście do zgłoszenia i jego kompletności przez organ ochrony środowiska. Słusznie zauważa Wojciech Radecki, iż „Pierwszym podstawowym obowiązkiem organu ochrony środowiska jest przyjęcie zgłoszenia, gdyż to akcentuje art. 24 
ust. 1. Byłbym jednak skłonny bronić poglądu, że obowiązek przyjęcia dotyczy tylko takiego zgłoszenia, które odpowiada wymaganiom określonym w art. 24 ust. 3"2. Bez wątpienia Autor ten wiąże negatywny dla zgłaszającego skutek, jaki się wiąże z naruszeniem art. 24 ust. 3 ustawy szkodowej. Skutek ten polega zdaniem Radeckiego na zwolnieniu organu administracji publicznej z obowiązku przyjęcia zgłoszenia. Jest to bez wątpienia nawiązanie do kwestii ciężaru dowodu w znaczeniu formalnym.

Podobne stanowisko prezentuje Marek Górski twierdzący słusznie, iż „Zgodnie natomiast z art. 24 ust. 2 organizacja ekologiczna natomiast lub organ administracji niewątpliwie już nie muszą być wykazywać bezpośredniego dotknięcia szkodą czy zagrożeniem, powinny jednak te podmioty wykazać zagrożenie lub szkodę $\mathrm{w}$ środowisku, traktowanym jako dobro wspólne. Podmioty te występują więc niejako w imieniu środowiska, a nie w imieniu własnym"3.

Także i w tym stanowisku widać wyraźne wskazanie, iż to na podmiocie zgłaszającym spoczywa obowiązek wykazania zagrożenia lub szkody w środowisku. Wprawdzie autor ten odnosi to do środowiska jako dobro wspólnego, niemniej chodzi tu o obowiązek wykazania, który jest niezależny od tego, czy chodzi o środowisko, jako dobro wspólne. Dobro wspólne, odnoszące się do środowiska jedynie legitymuje podmioty zgłaszające, ale nie determinuje samego ciężaru dowodu.

Podobnie wypowiada się Kamila Kwaśnicka, która zauważa, iż „wymagana jest także, w miarę możliwości, dokumentacja, która będzie stanowiła potwierdzenie wystąpienia bezpośredniego zagrożenia szkodą w środowisku czy też szkody w środowisku, albo będzie wskazywała odpowiedzialny podmiot korzystający ze środowiska"4.

2 W. Radecki, Ustawa o zapobieganiu szkodom $w$ środowisku i ich naprawie. Komentarz, Warszawa 2007, s. 110.

3 M. Górski, Odpowiedzialność administracyjnoprawna $w$ ochronie środowiska, Warszawa 2008, s. 49.

4 K. Kwaśnicka, Odpowiedzialność administracyjna $w$ prawie ochrony środowiska, Warszawa 2011,s. 185 
Podstawowy rodzaj wykładni - wykładnia językowa, prowadzi do właściwego wniosku, iż ciężar dowodu okoliczności bezpośredniego zagrożenia szkodą $\mathrm{w}$ środowisku lub szkody w środowisku obciąża według tego przepisu podmiot zgłaszający ${ }^{5}$. Ustawodawca wyraźnie wskazuje, że zgłaszający powinien wykazać, w miarę możności, okoliczności, od których jest uzależniona odpowiedzialność podmiotu korzystającego ze środowiska. Nie budzi również wątpliwości to, że obciążenie ciężarem dowodu zarówno w wymiarze procesowym, jak i w wymiarze materialnoprawnym, obciąża zgłaszającego co do zasady. Rozwiązanie przyjęte w art. 24 ustawy szkodowej różni się więc od modelu rozkładu ciężaru dowodu, przyjętego w postępowaniu administracyjnym ogólnym, a wyznaczonego przez art. 7 i $77 \mathrm{kpa}$.

W piśmiennictwie zwrócono jednak słusznie uwagę, że odróżniać należy obowiązek gromadzenia materiału dowodowego od problematyki ciężaru dowodu ${ }^{6}$. Przy tym piśmiennictwo, jak i orzecznictwo nie wyklucza stosowania w postępowaniu administracyjnym reguł ciężaru dowodu, wynikających z art. $6 \mathrm{kc}^{7}$. Uzasadnia się to ważkim argumentem, iż kpa nie zawiera samodzielnej podstawy prawnej regulującej ciężar dowodu. Nie podejmując głębszej argumentacji, poprzestać można na stwierdzeniu, że nie w każdym przypadku i nie w każdym postępowaniu ciężar dowodu zawsze i wszędzie obciąża jedynie organ administracji publicznej.

Z kolei wyjątkiem od wyjątku określonego w art. 24 ustawy szkodowej jest reguła, iż zgłaszający jest zobowiązany zaproponować dowody w miarę możności. Ustawodawca zwalnia zatem zgłaszającego z ciężaru udowodnienia istnienia przesłanek odpowiedzialności za szkodę w środowisku lub bezpośrednie zagrożenie szkodą w środowisku, jeżeli zgłaszający przedłożył dowody w „miarę możności”. Użycie tego sformułowania

5 Por. B. Rakoczy, Ciężar dowodu $w$ polskim prawie ochrony środowiska, Warszawa 2010.

6 W literaturze tak m.in. R. Kędziora, Kodeks postępowania administracyjnego. Komentarz, Warszawa 2008, s. 417.

7 Dz.cyt., s. 417 i przywołane tam orzecznictwo. 
„W miarę możności" pełni w art. 24 ustawy szkodowej funkcję instrumentu łagodzącego rygoryzm ciężaru dowodów. Prawodawca ma bowiem pełną świadomość, jakie są skutki niesprostania wymogom ciężaru dowodu zarówno w jego wymiarze formalnoprawnym, jak i materialnoprawnym. Podmiot, który nie sprostał ciężarowi dowodu, przegrywa postępowanie. Łagodząc ów rygoryzm ciężaru dowodu, ustawodawca uwzględnił dwie istotne okoliczności.

Po pierwsze, wziął pod uwagę, że jednak postępowanie według ustawy szkodowej jest postępowaniem administracyjnym. Miał więc świadomość, że wprowadzając rozwiązania z art. 24 ustawy szkodowej, czyni wyjątek od reguł dowodowych, przyjętych w ogólnym postępowaniu administracyjnym. Miał również na względzie okoliczność, iż w postępowaniu szkodowym nie można stosować takiego samego rygoryzmu uchybienia obowiązkom ciężaru dowodu jak to ma miejsce w prawie i postępowaniu cywilnym.

Gdyby przyjąć cywilistyczny punkt widzenia, to należałoby przyjąć, że zgłaszający szkodę w środowisku jest w stanie sprostać wszystkim wymogom wykazania wszystkich przesłanek odpowiedzialności za szkodę w środowisku lub bezpośrednie zagrożenie szkodą w środowisku, tymczasem nawet ze względów obiektywnych zgłaszający nie jest w stanie uzyskać wszystkich dowodów. Wynika to również z tego, że przesłanki odpowiedzialności w ustawie szkodowej są sformalizowane. Ponadto, wszystkie przesłanki muszą być spełnione łącznie. A jest ich niemało. Stąd też ustawodawca ma świadomość, że nie można przerzucać na zgłaszającego całego ciężaru dowodu i wprowadza klauzulę łagodzącą w miarę możności.

Drugim powodem wprowadzenia klauzuli łagodzącej rygoryzm ciężaru dowodu jest dobro chronione. Ustawodawca ma świadomość, że przedmiotem postępowań prowadzonych na podstawie ustawy szkodowej jest środowisko. Jego ochrona jest wartością konstytucyjną. Jak wynika art. 5 Konstytucji Rzeczypospolitej Polskiej z dnia 2 kwietnia 1997 roku$^{8}$ : „Rzeczpospolita Polska strzeże niepodległości i nienaruszalności swojego 
terytorium, zapewnia wolności i prawa człowieka i obywatela oraz bezpieczeństwo obywateli, strzeże dziedzictwa narodowego oraz zapewnia ochronę środowiska, kierując się zasadą zrównoważonego rozwoju".

Z kolei w myśl art. 74 ust. 2 Konstytucji RP „Ochrona środowiska jest obowiązkiem władz publicznych".

Z obu tych cytowanych przepisów jednoznacznie wynika, że ochrona środowiska jest zadaniem władz publicznych. Gdyby przyjąć cywilistyczne podejście do problematyki ciężaru dowodu, to organ powinien odmówić prowadzenia postępowania w przypadku niepowodzenia ciężaru dowodu w każdej sytuacji, niezależnie od tego, czy podjęcia jego działań wymaga ochrona środowiska, czy też nie. Klauzula łagodząca ma ten skutek, że organ może przeprowadzać postępowanie dowodowe we własnym zakresie niezależnie od stanowiska zgłaszającego, jednak przeprowadzanie dowodu przez organ jest wyjątkiem w art. 24 ustawy szkodowej.

Klauzula łagodząca „w miarę potrzeby” ma ten skutek, że uznać można, iż zgłaszający sprostał wymogom ciężaru dowodu, nawet jeśli nie wszystkie okoliczności, od zaistnienia których ustawodawca uzależnił odpowiedzialność, zostały w sensie formalnoprawnym i materialnoprawnym wykazane. Jednak skorzystanie z tej klauzuli wymaga wykazania przez zgłaszającego, iż dołożył on wszelkich starań i wykorzystał wszelkie dostępne mu środki dla uzyskania określonego dowodu lub dowodów, a pomimo to obiektywnie nie udało mu się wszystkich okoliczności odpowiedzialności podmiotu korzystającego ze środowiska wykazać. Ustawodawca nie oczekuje zatem od zgłaszającego nadzwyczajnych dowodów, gdyż wystarczy, że dołożył on starań, aby określone okoliczności wykazać.

Myli się zatem NSA, stwierdzając, jakoby art. 24 ustawy szkodowej nie był wyjątkiem od zasad przyjętych w art. 7 i 77 kpa. Przede wszystkim pogląd NSA pomija literalne brzmienie tego przepisu i nie dostrzega specyfiki rozwiązań przyjętych w tej ustawie szkodowej. Gdyby przyjąć punkt widzenia NSA, jakoby art. 24 ustawy szkodowej nie stanowił wyjątku od rozkładu ciężaru dowodu z art. 7 i 77, to straciłaby sens ta część art. 24, która odnosi się do obowiązków w zakresie ciężaru do- 
wodów, obciążających zgłaszającego, a przede wszystkim ust. 3 i 4. Straciłaby również sens klauzula łagodząca i stawałaby się zbędnym elementem art. 24 ustawy szkodowej. Jeśli art. 24 ustawy szkodowej nie jest wyjątkiem od rozkładu ciężaru dowodu przyjętego w ogólnym postępowaniu administracyjnym, to jaki jest sens istnienia klauzuli łagodzącej. Przy przyjęciu punktu widzenia NSA klauzula ta straci po prostu swój sens. Po co odwoływać się do klauzuli „w miarę możności”, skoro i tak ciężar dowodu obciąża organ administracji publicznej na podstawie art. 7 i 77 kpa. Wykładnia przepisu prowadząca do ustalenia, że jego określona część jest zbędna dla wyrażenia woli prawodawcy, jest wykładnią zakazaną.

Nie wolno interpretować przepisu w taki sposób, że określone jego części staną się zbędne9. Tak właśnie postąpił w przedmiotowej sprawie NSA, gdyż stwierdzenia, iż art. 24 ustawy szkodowej nie stanowi wyjątku od zasady rozkładu ciężaru dowodu, powoduje, że niektóre sformułowania tego przepisu stają się po prostu zbędne. Zdecydowanie należy krytycznie ocenić wątpliwe stanowisko NSA i podkreślić, że art. 24 ustawy szkodowej jest właśnie przepisem wyjątkowym w stosunku do reguł ciężaru dowodu przyjętych w ogólnym postępowaniu administracyjnym. Dopiero przyjęcie, iż to jednak ciężar dowodu obciąża, co do zasady, podmiot zgłaszający, nadaje temu przepisowi sens, a przede wszystkim nadaje sens istnieniu klauzuli łagodzącej „w miarę możności”.

Wprawdzie kwestia ciężaru dowodu nie zaważyła na rozstrzygnięciu sprawy przez NSA, gdyż skarga kasacyjna została oddalona, niemniej jednak prezentowany pogląd, co do rozkładu ciężaru dowodu, może wywołać dla praktyki negatywne skutki polegające na kreowaniu zgłoszeń całkowicie bezzasadnych, tylko z powołaniem się na stanowisko NSA w kwestii ciężaru dowodów.

Zadać sobie należy pytanie, jaki cel przyświecał prawodawcy europejskiemu, a w ślad za nim prawodawcy polskiemu, którzy w taki, a nie inny sposób ukształtowali kwestie ciężaru dowodu. Bez wątpienia chodziło tutaj o wyeliminowanie bezza-

9 Por. L. Morawski, Zasady wykładni prawa, Toruń 2010, s. 122. 
sadnych zgłoszeń, które absorbowałyby uwagę organu w sposób całkowicie nieracjonalny i zbędny ${ }^{10}$. Prawodawca polski nie zdecydował się na ograniczenie lub wyeliminowanie liczby zgłoszeń bezzasadnych, dając organom administracji publicznej możliwość wstępnej oceny zasadności skargi, natomiast zdecydował się na osiągnięcie tego samego celu, właśnie poprzez przerzucenie ciężaru dowodu na podmiot zgłaszający. Przedkładając stosowne dowody, organ zgłaszający jednocześnie uwiarygadnia zasadność swojego zgłoszenia i je uprawdopodabnia. Przedłożenie tych dowodów eliminuje też fazę wstępnej oceny. Organ przechodzi od razu do sprawdzenia, czy zgłoszenie rzeczywiście dotyczy szkody w środowisku, lub jej bezpośredniego zagrożenia. Zatem poziom oceny jest nieco wyższy, gdyż organ korzysta już z podstawowych informacji i dowodów. Pogląd NSA wypacza w istocie również i t wartość, która przyświecała prawodawcy.

Reasumując, choć samo orzeczenie NSA należy zaaprobować, gdyż skarga kasacyjna została oddalona, to jednak krytycznie należy ocenić pogląd tego Sądu, według którego ciężar dowodu w znaczeniu formalnym obciąża nie zgłaszającego, a organ administracji publicznej. NSA stwierdził, że odwrócenie ciężaru dowodu jest możliwe tylko wtedy, gdy wynika to z konkretnej normy prawnej. Zdaniem tego Sądu taką normą prawną nie jest jednak art. 24 ustawy szkodowej. Pogląd ten stoi w sprzeczności zarówno z wykładnią językową art. 24 ustawy szkodowej, jak i z wykładnią celowościową. Ustawodawca zakłada, iż zgłaszający wykaże w miarę możności przesłanki odpowiedzialności ustawy szkodowej. Przerzucenie ciężaru dowodu na zgłaszającego łagodzone jest klauzulą w miarę możności. Oznacza to, że prawodawca polski nie podchodzi do problematyki ciężaru dowodu zgodnie z rygoryzmem charakterystycznym dla prawa cywilnego, ale podchodzi do tego zagadnienia w sposób umiarkowany i racjonalny. Powołanie się na klauzulę

10 Por. B. Rakoczy, Odpowiedzialność za szkodę w środowisku. Dyrektywa Parlamentu Europejskiego i Rady 2004/35. Komentarz, Toruń 2010; M. Hinteregger (red.), Environmental Liability and Ecological Damage in European Law, Cambridge 2008. 
łagodzącą wymaga również wykazania, że dołożono starań dla pozyskania dowodów.

W rozwiązaniach przyjętych w art. 24 ustawy szkodowej opatrywać należy środka eliminującego zgłoszenia, oczywiście bezzasadne. Opowiedzieć się należy za poglądem, iż art. 24 jest przepisem szczególnym wobec art. 7 i 77 kpa i ciężar dowodu, co do zasady, obciąża podmiot zgłaszający. 